\title{
Two-billion-year-old volcanism on the Moon from Chang'e-5 basalts
}

https://doi.org/10.1038/s41586-021-04100-2

Received: 28 July 2021

Accepted: 6 October 2021

Published online: 19 October 2021

\section{Open access}

Check for updates

\author{
Qiu-Li Li' ${ }^{1,6}$, Qin Zhou ${ }^{2,6}$, Yu Liu', Zhiyong Xiao ${ }^{3}$, Yangting Lin ${ }^{4}$, Jin-Hua Li ${ }^{4}$, Hong-Xia Ma', \\ Guo-Qiang Tang', Shun Guo', Xu Tang ${ }^{4}$, Jiang-Yan Yuan', Jiao Li', Fu-Yuan Wu', \\ Ziyuan Ouyang ${ }^{5}$, Chunlai $\mathrm{Li}^{2 \bowtie} \&$ Xian-Hua $\mathrm{Li}^{1 凶}$
}

\begin{abstract}
The Moon has a magmatic and thermal history that is distinct from that of the terrestrial planets ${ }^{1}$. Radioisotope dating of lunar samples suggests that most lunar basaltic magmatism ceased by around $2.9-2.8$ billion years ago $(\mathrm{Ga})^{2,3}$, although younger basalts between $3 \mathrm{Ga}$ and $1 \mathrm{Ga}$ have been suggested by crater-counting chronology, which has large uncertainties owing to the lack of returned samples for calibration $^{4,5}$. Here we report a precise lead-lead age of 2,030 \pm 4 million years ago for basalt clasts returned by the Chang'e- 5 mission, and a ${ }^{238} \mathrm{U} /{ }^{204} \mathrm{~Pb}$ ratio $(\mu \text { value })^{6}$ of about 680 for a source that evolved through two stages of differentiation. This is the youngest crystallization age reported so far for lunar basalts by radiometric dating, extending the duration of lunar volcanism by approximately 800-900 million years. The $\mu$ value of the Chang'e- 5 basalt mantle source is within the range of low-titanium and high-titanium basalts from Apollo sites ( $\mu$ value of about 300-1,000), but notably lower than those of potassium, rare-earth elements and phosphorus (KREEP) and high-aluminium basalts ${ }^{7}$ ( $\mu$ value of about $2,600-3,700$ ), indicating that the Chang'e-5 basalts were produced by melting of a KREEP-poor source. This age provides a pivotal calibration point for crater-counting chronology in the inner Solar System and provides insight on the volcanic and thermal history of the Moon.
\end{abstract}

Even though mare basalt covers only roughly $17 \%$ of the surface of the Moon ${ }^{8}$, its protracted formation record spans more of the lunar magmatic history than any other geological unit. Radioisotope age studies of basaltic samples returned by the Apollo and Luna missions and lunar meteorites have revealed that basaltic magmatism on the Moon occurred between around 4.4 billion years ago $(\mathrm{Ga})\left(\right.$ ref. $\left.^{9}\right)$ and around 2.9-2.8 Ga (refs. ${ }^{2,3}$ ), with two major pulses around 3.95-3.58 Ga and 3.38-3.08 Ga $\left(\right.$ ref. $^{10}$ ). However, crater-counting chronology suggests a more extended period of basalt volcanism occurring between around $4.0 \mathrm{Ga}$ and around $1.2 \mathrm{Ga}$ (refs. ${ }^{4,11}$ ). Some of the youngest mare basalt units in Oceanus Procellarum have been estimated to be around 2.2-1.2 Ga (refs. ${ }^{4,11,12}$ ), which would putatively expand the duration of mare volcanism to over roughly three billion years. Whether or not mare volcanism continued to around 2.2-1.2 Ga, or perhaps even younger in small eruptions ${ }^{5}$, has long been a major question. These young crater-counting ages, however, have not been confirmed by radioisotopic ages. The actual end of mare volcanism has not yet been constrained by radioisotopic dating owing to the lack of available samples from these younger volcanic units, which have incurred fewer impacts.

\section{Age of Chang'e-5 basalt}

Precise and accurate age determination of these young mare basalts is crucial not only for unravelling the timing and duration of lunar volcanism but also for investigating late-stage basaltic petrogenesis and the melting of lunar mantle sources that are relevant to the thermal and chemical evolution of the Moon. The landing site of Chang'e-5, China's first lunar-sample-return mission, was selected because it is located on one of the youngest mare basalt units northeast of Mons Rümker in northern Oceanus Procellarum ${ }^{13}$. Therefore, basalts returned by Chang'e- 5 provide an opportunity to understand the timing and mechanism of one of the youngest units of mare volcanism on the Moon. In addition, precise radioisotopic dating of these newly returned basalts has a critical potential to verify and calibrate lunar impact crater-counting chronology, which is the main basis for dating most geological units of the other inner Solar System bodies.

The Chang'e-5 samples studied in this research were scooped from the lunar regolith surface and include three one-inch epoxy mounts (samples CE5C0000YJYX041GP and CE5C0000YJYX042GP with two basalt clasts larger than $1.5 \mathrm{~mm}$ in each, and sample CE5C0800YJFM00102GP with $20 \mathrm{mg}$ of soil) and two aliquots of soils (samples CE5C0100YJFM00103 of $1 \mathrm{~g}$ and CE5C0400YJFM00406 of $2 \mathrm{~g}$ ) allocated by the China National Space Administration. Around 800 lithic clasts (greater than $0.25 \mathrm{~mm}$ ) were randomly picked from the two soil samples to make additional epoxy mounts. The lithic clasts in the soils are composed of about $45 \%$ basalt and about $55 \%$ breccia. The breccia clasts are dominated by basalt fragments (more than $80 \%$ ) with minor impact melt and agglutinate. The majority of the basalt clasts

${ }^{1}$ State Key Laboratory of Lithospheric Evolution, Institute of Geology and Geophysics, Chinese Academy of Sciences, Beijing, China. ${ }^{2}$ Key Laboratory of Lunar and Deep Space Exploration,

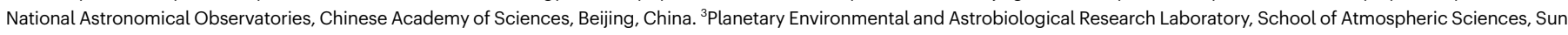
Yat-sen University, Zhuhai, China. ${ }^{4}$ Key Laboratory of Earth and Planetary Physics, Institute of Geology and Geophysics, Chinese Academy of Sciences, Beijing, China. ${ }^{5} \mathrm{Center}$ for Lunar and

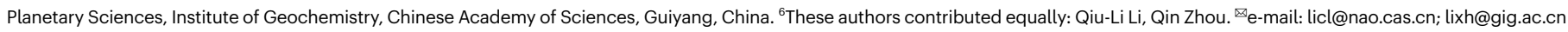



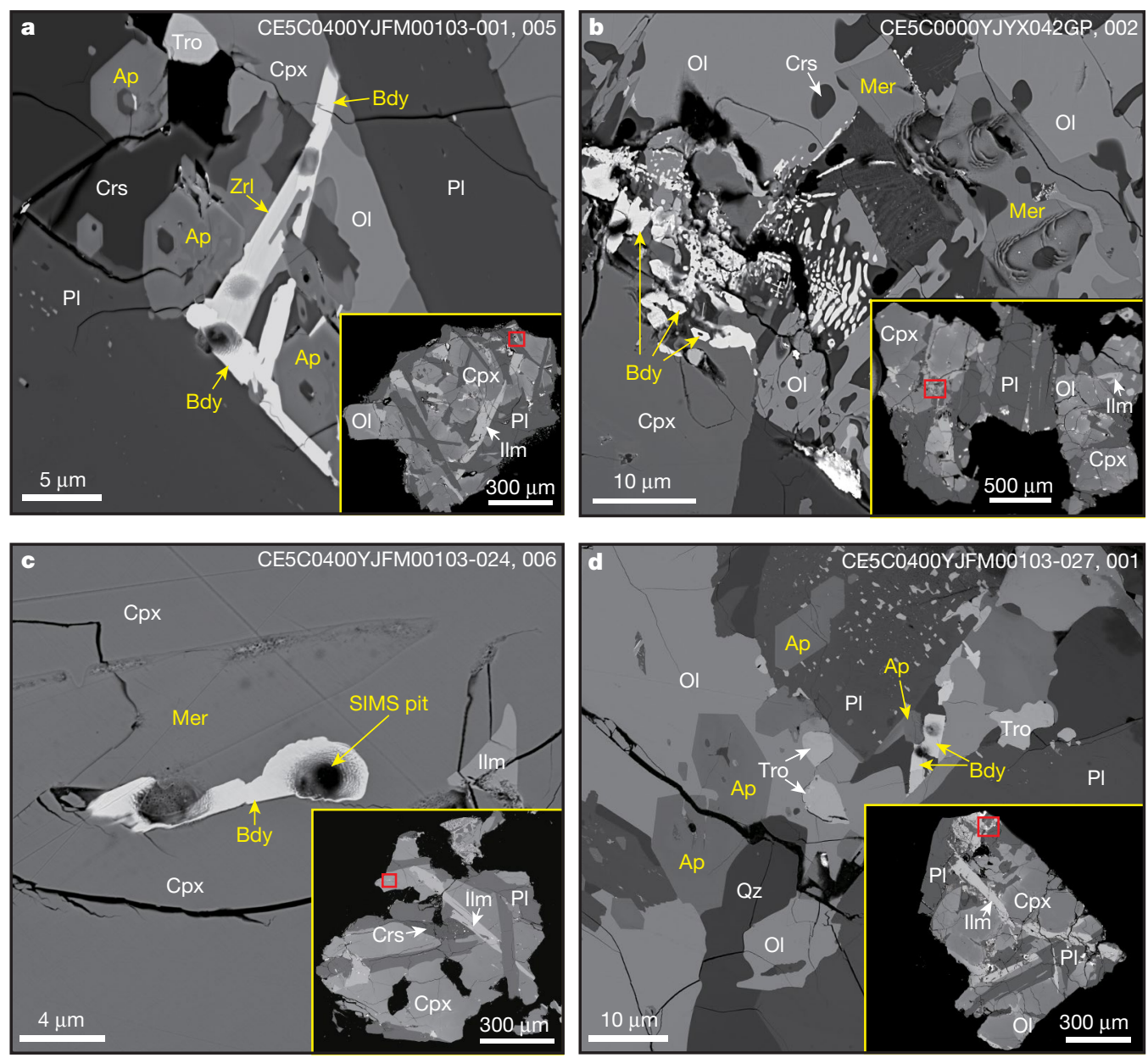

Fig. 1 Back-scattered electron images of representative dated minerals in the Chang'e- 5 basalt clasts. a, Intergrown texture of baddeleyite, zirconolite and apatite in a subophitic basalt clast.b, Subhedral baddeleyite and merrillite occur within mesostasis composed of Fe-rich olivine, clinopyroxene, K-feldspar and troilite in a poikilitic clast.c, Baddeleyite and merrillite in a subophitic clast. d, Euhedral apatite and baddeleyite occur as intergranular phases associated with Fe-rich olivine in an equigranular basalt clast. Pits in Zr-bearing minerals are

(about $80 \%$ ) show subophitic and poikilitic textures, with the remainder being porphyritic and equigranular textures. The basalt clasts have various grain sizes (approximately $10-600 \mu \mathrm{m}$ ), but similar major mineral constituents of clinopyroxene, plagioclase, olivine, ilmenite, and rare troilite and cristobalite (Fig. 1). The euhedral-to-subhedral phosphate minerals apatite and merrillite are found in all types of basalt clast (Fig. 1, Extended Data Figs. 1, 2, Supplementary Table1) and commonly occur along the margins of iron (Fe)-rich olivine, clinopyroxene and ilmenite. The minor zirconium ( $\mathrm{Zr}$ )-bearing minerals baddeleyite, zirconolite and tranquillityite are fine-grained (3-8 $\mu \mathrm{m})$, euhedral to subhedral in shape, interstitial-to-major silicate phases, and common in coarse-grained (greater than $100 \mu \mathrm{m}$ ) poikilitic, equigranular and subophitic basalt clasts, but not in porphyritic basalt clasts (Fig.1, Extended Data Figs. 1, 2, Supplementary Table 2). In some cases, $\mathrm{Zr}$-bearing and phosphate minerals show intergrowth textures with each other (Fig. 1a, c, d, Extended Data Fig. 2), which suggests that they formed during the same final crystallization stage of the magma. Forty-seven representative basalt clasts with various textures were used for radioisotopic dating.

The uranium $(\mathrm{U})$-lead $(\mathrm{Pb})$ isotopic compositions of various mineral phases in Chang'e-5 basalt clasts were determined using a CAMECA IMS $1280 \mathrm{HR}$ secondary ion mass spectrometer (SIMS) (complete dataset presented in Supplementary Table 3). Zr-bearing minerals, phosphates

the in situ analytical spots from SIMS. The areas of dated minerals in the clasts are outlined (red rectangles) in the corresponding insets. Ap, apatite; Bdy, baddeleyite; Cpx, clinopyroxene; Crs, cristobalite; Ilm, ilmenite; Mer, merrillite; $\mathrm{Ol}$, olivine; $\mathrm{Pl}$, plagioclase; $\mathrm{Qz}$, quartz; Tro, troilite; Zrl, zirconolite. Codes in the top right corner indicate sample name, mount number and grain number on the mount $(\mathbf{a}, \mathbf{c}, \mathbf{d})$, or mount name and grain number $(\mathbf{b}$, note: this is a one-inch epoxy mount sample with two basalt grains on it.).

and others (that is, plagioclase, pyroxene and matrix minerals) were analysed using a primary $\mathrm{O}^{-}$beam with roughly $3-\mu \mathrm{m}$, roughly $8-\mu \mathrm{m}$ and roughly $30-\mu \mathrm{m}$ spot sizes, respectively (Methods). Pb isotope analyses on 17 poikilitic clasts, 18 subophitic clasts and 10 equigranular clasts (Extended Data Table 1) were used to construct three $\mathrm{Pb}-\mathrm{Pb}$ leftmost isochrons ${ }^{10}$. The radiogenic ${ }^{207} \mathrm{~Pb} /{ }^{206} \mathrm{~Pb}$ ratios of $y$ intercepts are translated to $\mathrm{Pb}-\mathrm{Pb}$ ages of $2,027 \pm 7$ million years ago (Ma) $(95 \%$ confidence level, and hereafter except where otherwise noted), 2,030 \pm 6 Ma and $2,034 \pm 8 \mathrm{Ma}$, respectively (Extended Data Fig. 3a-f). Forty-four Pb isotope analyses were conducted on plagioclase, pyroxene and matrix from two fine-grained porphyritic clasts (without visible $\mathrm{Zr}$-bearing minerals) and yielded a leftmost isochron $\mathrm{Pb}-\mathrm{Pb}$ age of 2,027 $\pm 54 \mathrm{Ma}$ (Extended Data Fig. 3g, h). Despite the distinct petrographic textures in Chang'e- 5 basalts, these four isochrons have consistent $y$ intercepts and slopes within uncertainties (Extended Data Fig.3), indicating both their identical age and derivation from most probably the same source. Taken together, a total of 159 analyses with negligible terrestrial $\mathrm{Pb}$ contamination for various mineral phases form an integrated isochron yielding a Pb-Pb age of 2,030 $\pm 4 \mathrm{Ma}$ (Fig. 2). The age is interpreted as the best estimate of the crystallization age of the Chang'e- 5 basalts given that all the clasts studied here show pristine magmatic textures without evident overprinting from shock metamorphism (Fig. 1). This age represents the youngest crystallization age reported so far 

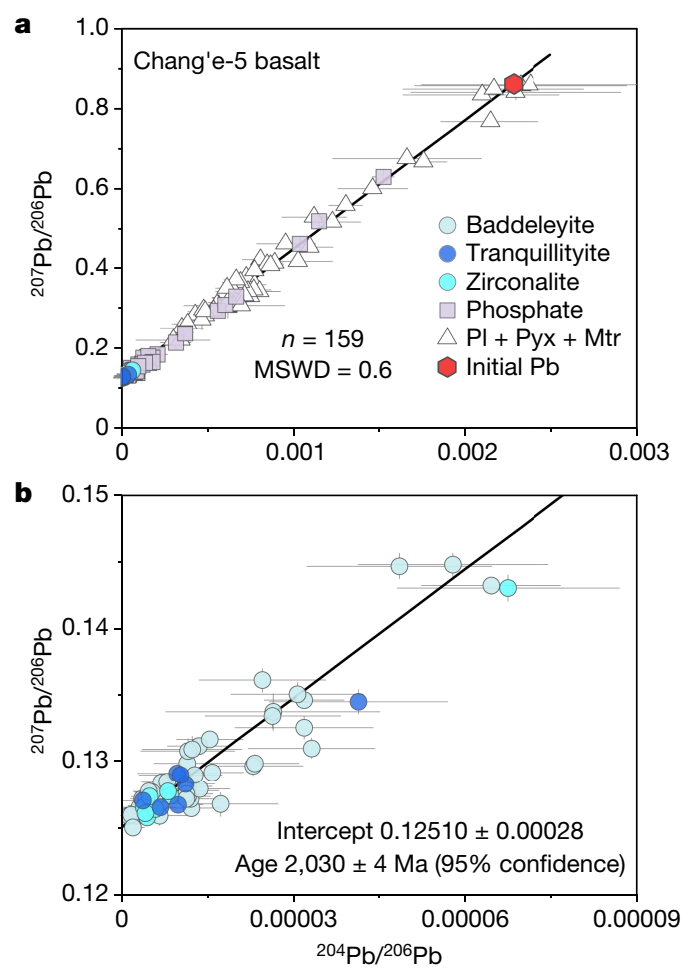

Fig. $2 \mid \mathbf{P b}-\mathbf{P b}$ isochron for the Chang'e-5 basalts. a, The integrated $\mathrm{Pb}-\mathrm{Pb}$ isochron showing the mixing line between the $y$ intercept as radiogenic ${ }^{207} \mathrm{~Pb} /{ }^{206} \mathrm{~Pb}$ and the initial $\mathrm{Pb}$ compositions $\left({ }^{204} \mathrm{~Pb} /{ }^{206} \mathrm{~Pb}=0.00228 \pm 0.00011\right.$, $\left.{ }^{207} \mathrm{~Pb} /{ }^{206} \mathrm{~Pb}=0.860 \pm 0.019\right) . \mathrm{b}$, The enlarged lowest part of the isochron in a highlighting the measurements of $\mathrm{Zr}$-bearing minerals. The black line is the best-fitted isochron with an equation of $y=(323 \pm 7) x+(0.12510 \pm 0.00028)$. Error bars represent $1 \sigma$ s.e. Mtr, matrix; $\mathrm{Pl}$, plagioclase; Pyx, pyroxene.

for lunar basaltic rocks by the radiometric method and thus extends the range of radioisotopic ages of lunar basalt by about $800-900 \mathrm{Myr}$. Therefore, this study provides conclusive evidence that magmatic activity on the Moon persisted until at least $2 \mathrm{Ga}$. This insight into the existence of this youngest-known volcanism provides a critical constraint for understanding the thermal mechanisms behind the longevity of lunar magmatism.

\section{Mantle source signature}

One of the leading mechanisms considered for sustaining such young lunar volcanism is potassium, rare-earth elements and phosphorus (KREEP)-related radiogenic heating in the basalt source ${ }^{1,3,14}$; thus characterizing the geochemistry of the mantle source of this youngest-dated mare basalt reported so far provides a critical test of this hypothesis. The initial $\mathrm{Pb}$ isotopic composition of the basalts and corresponding time-integrated $\mu$ value $\left({ }^{238} \mathrm{U} /{ }^{204} \mathrm{~Pb}\right.$ ratio) for their mantle source can fingerprint the Chang'e-5 basalt mantle source and its chemical evolution $^{6,7,10}$. Five of the $106 \mathrm{U} / \mathrm{Pb}$ analyses for rock-forming minerals (mainly plagioclase) show negligible $\mathrm{U}\left(\right.$ with ${ }^{238} \mathrm{UO}^{+} /{ }^{208} \mathrm{~Pb}^{+}$ratios of $<0.01$ ) and clustered ${ }^{207} \mathrm{~Pb} /{ }^{206} \mathrm{~Pb}$ values of $0.855-0.872$ (Supplementary Table 3 ). Thus, their weighted mean of $0.860 \pm 0.019$ ( 2 s.e., $n=5$, mean squared weighted deviation $=0.11$ ) provides the best estimate for the initial ${ }^{207} \mathrm{~Pb} /{ }^{206} \mathrm{~Pb}$ ratio of the Chang'e-5 basalts (Extended Data Fig. 4 ). The initial ${ }^{204} \mathrm{~Pb} /{ }^{206} \mathrm{~Pb}$ ratio, however, is difficult to measure precisely and accurately owing to extremely low ${ }^{204} \mathrm{~Pb}$ counts (less than 0.05 counts per second (cps)) (Supplementary Table 3). Alternatively, it can be calculated as $0.00228 \pm 0.00011$ ( 2 s.e.) based on the best-fit $\mathrm{Pb}-\mathrm{Pb}$ isochron (Fig. 2a) and the aforementioned best estimate of the initial ${ }^{207} \mathrm{~Pb} /{ }^{206} \mathrm{~Pb}$ ratio. This calculated initial ${ }^{204} \mathrm{~Pb} /{ }^{206} \mathrm{~Pb}$ ratio is consistent

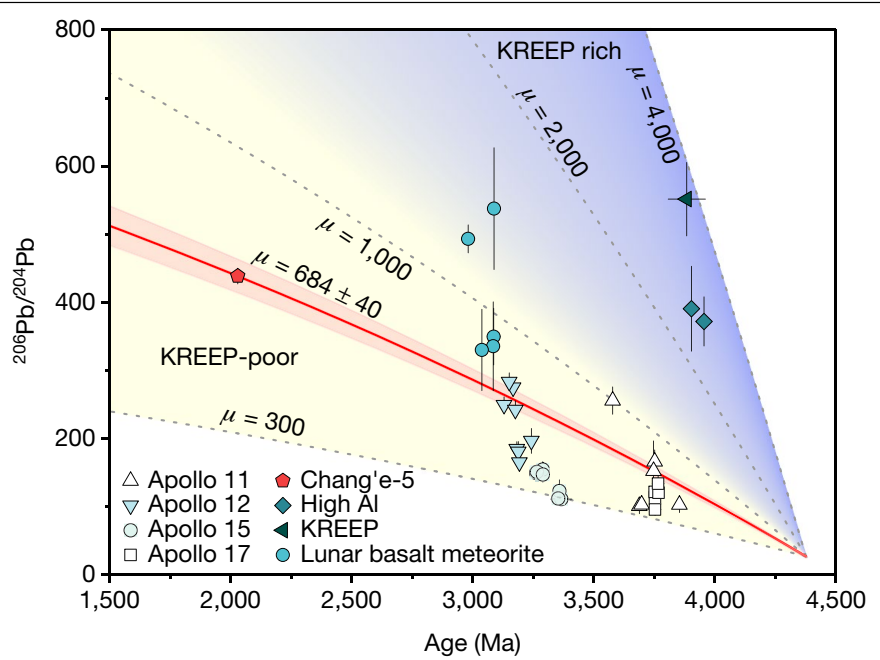

Fig. 3 | Initial ${ }^{206} \mathrm{~Pb} /{ }^{204} \mathrm{~Pb}$ ratios versus crystallization ages of the lunar basalts and meteorites. The lines represent the two-stage $\mathrm{Pb}$ isotope evolution of lunar mantle sources at given $\mu$ values $^{6}$. The gradient areas are associated with KREEP-poor (yellow) to KREEP-rich (blue) mantle sources according to $\mu$ values. The Apollo and meteorite data are from refs. ${ }^{6,7,10}$. Error bars are $2 \sigma$ s.e. A11, Apollo 11 high-Ti basalts; A12, Apollo 12 low-Ti basalts; A15, Apollo low-Ti basalts; A17, Apollo 17 high-Ti basalts; High-Al, Apollo 14 high-Al basalts; KREEP, Apollo 15 KREEP basalts; Lunar basalt meteorite, low-Ti and very-low-Tibasaltic meteorites (NWA 4734 and NWA 773 clan).

within errors with the weighted mean of $0.00235 \pm 0.00043$ ( 2 s.e.) for the two lowest measured ${ }^{204} \mathrm{~Pb} /{ }^{206} \mathrm{~Pb}$ ratios (Supplementary Table 3), justifying the rationale of the calculation.

Determination of the $\mu$ value of a basalt mantle source is dependent on the lunar $\mathrm{Pb}$-isotope evolution model $\mathrm{l}^{6,7,10}$. On the basis of the lunar magma ocean (LMO) model ${ }^{15}$ that presumably generated all major lunar silicate reservoirs, including the sources for lunar basalts, a two-stage model for lunar $\mathrm{Pb}$-isotopic evolution is proposed ${ }^{6,7}$. The evolution of the $\mathrm{Pb}$ isotopes of a basalt source starts from $t_{0}$ (around $4,500 \mathrm{Ma})^{16}$ for Moon formation with $\mu_{1}=462 \pm 46$ for the $\mathrm{LMO}^{6}$, to $t_{1}$ (around 4,420-4,300 Ma) ${ }^{17,18}$ for LMO crystallization and the formation of major geochemically distinct reservoirs with different $\mu_{2}$ values, to $t_{2}$ for mare basalt formation with the initial $\mathrm{Pb}$ isotopes. Although $t_{1}$ remains uncertain, its age range has little effect on the calculated $\mu_{2}$ values (Extended Data Fig. 5). Thus, for comparison with previous results ${ }^{6,7}$, a $t_{1}$ of $4,376 \pm 18$ Ma was selected to calculate a two-stage $\mu$ value of $684 \pm 40$ for the Chang'e- 5 basalt source (Fig. 3 ). This $\mu$ value is within the range $(\mu \approx 300-1,000)$ of the low-titanium (Ti) and high-Ti Apollo basalts, but considerably lower than those $(\mu \approx 2,600-3,700)$ of the KREEP and high-aluminium (Al) basalts $s^{6,7}$ (Fig. 3). This marked difference suggests that the Chang'e-5 basalts from the Procellarum KREEP Terrane were most probably produced by the melting of a KREEP-poor source. An apparent increase in $\mu$ values from around 3.4-3.0 Ga for low-Ti Apollo basalts and low-Ti and very-low-Ti basaltic meteorites (NWA 4734 and NWA 773 clan) suggests a progressive contribution of a KREEP-like component in such rocks ${ }^{6,7,10}$. However, the Chang'e-5 basalts do not follow this trend, indicating that KREEP-like components were not involved in our samples, neither in the deep source nor during shallow contamination of the KREEP material. Corroborating evidence for a non-KREEP source for the Chang'e- 5 basalts is provided by strontium-neodymium ( $\mathrm{Sr}-\mathrm{Nd})$ isotopes ${ }^{19}$, but the results in this study using the radioactive element $\mathrm{U}$ offer direct evidence for heat-producing elements not being concentrated in the Chang'e- 5 basalt mantle source. Thus, these results strongly suggest that the idea of KREEP-induced heating ${ }^{1,14,20}$ for the generation of these young lunar magmas requires further investigation or the consideration of other mechanisms. 


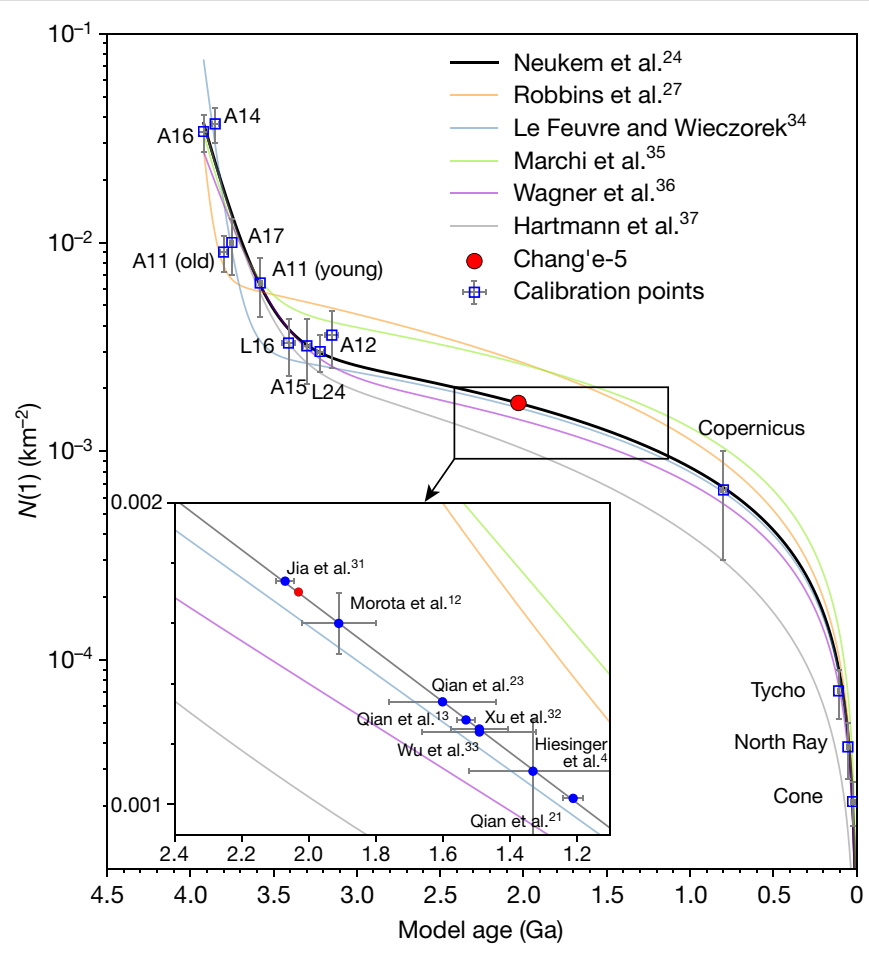

Fig. 4 | The critical reference point of the radioisotope age of the Chang'e-5 basalts for the lunar crater-counting chronology. The lines are colour-coded according to different models of the crater-counting chronology of the Moon. The red dot marks the radioisotope age of the Chang'e- 5 basalts and the translated crater density based on the crater-counting chronology function of ref. ${ }^{24}$. The blue squares are the calibration points established from Apollo and Luna samples ${ }^{27-30}$. The inset shows the various crater densities and model ages

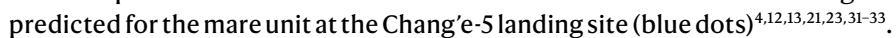
Error bars are $1 \sigma$ s.e. $N(1)$, number of craters with diameter $>1 \mathrm{~km}$. Different models in the main panel are from refs. ${ }^{24,27,34-37}$.

\section{Anchor point for cratering chronology}

Radioisotope ages provide the yardstick for calibrating the age information obtained from crater statistics. The mare unit on which Chang'e- 5 landed features both homogeneous reflectance spectra and surface morphology as seen from orbit ${ }^{21}$, and ballistic sedimentation modelling ${ }^{22,23}$ suggests a dominance of local mare basalts in the surface regolith. The basalt clasts returned show uniform geochemical characteristics ${ }^{19}$ and a consistent radioisotope age of 2,030 $\pm 4 \mathrm{Ma}$ (Fig.2), convincingly pointing to an affinity with the mare unit of the landing site. Therefore, our radioisotope age obtained for the newly returned Chang'e-5 samples offer an opportunity to confirm the first-order reliability of the lunar crater-counting chronology established by the Apollo and Luna missions ${ }^{24}$. The calculated model ages for the mare unit on which Chang'e-5 landed mostly range between around $2.2 \mathrm{Ga}$ and $1.5 \mathrm{Ga}$ using the prevailing crater-counting chronology of ref. ${ }^{24}$, within a difference of about $20 \%$ compared with the measured radioisotope age (Fig. 4). This difference is surprisingly consistent with that derived from a comparison of the current impact flux on the Moon from observations ${ }^{25}$ and prediction by crater-counting chronology ${ }^{24}$.

Substantial differences nonetheless exist among reported crater densities for the mare unit on which Chang'e-5 landed (Fig. 4), albeit a relatively simple geological context and the same crater-counting chronology model were used. Therefore, there is much potential to improve the accuracy of predictions by crater statistics. For the existing crater-counting chronology, Apollo and Luna samples have provided an initial database for ages ranging from around $4.0 \mathrm{Ga}$ to $3.1 \mathrm{Ga}$ as well as those younger than around $1 \mathrm{Ga}$ (Fig. 4). The age of $2.03 \mathrm{Ga}$ obtained for the Chang'e-5 basalts resides squarely in the centre of this large gap (Fig. 4), fulfilling the long-sought-after goal to bridge the unanchored middle portion of the lunar crater-counting chronology ${ }^{24}$ and improving this critical tool for dating unsampled surfaces on the Moon ${ }^{26}$, as well as for translating the lunar crater-counting chronology to the other planetary bodies ${ }^{24}$.

\section{Online content}

Any methods, additional references, Nature Research reporting summaries, source data, extended data, supplementary information, acknowledgements, peer review information; details of author contributions and competing interests; and statements of data and code availability are available at https://doi.org/10.1038/s41586-021-04100-2.

1. Shearer, C. K. et al. Thermal and magmatic evolution of the Moon. Rev. Mineral. Geochem. 60, 365-518 (2006).

2. Fernandes, V. A., Burgess, R. \& Turner, G. ${ }^{40} \mathrm{Ar}-{ }^{39} \mathrm{Ar}$ chronology of lunar meteorites northwest Africa 032 and 773. Meteorit. Planet. Sci. 38, 555-564 (2003)

3. Borg, L. E., Shearer, C. K., Asmenron, Y. \& Papike, J. J. Prolonged KREEP magmatism on the Moon indicated by the youngest dated lunar igneous rock. Nature 432, 209-211 (2004).

4. Hiesinger, H., Head, J. W. III, Wolf, U., Jaumann, R. \& Neukum, G. Ages and stratigraphy of mare basalts in Oceanus Procellarum, Mare Nubium, Mare Cognitum, and Mare Insularum. J. Geophys. Res. Planets 108, 5065-5091 (2003).

5. Braden, S. E. et al. Evidence for basaltic volcanism on the Moon within the past 100 million years. Nat. Geosci. 7, 878-791 (2014).

6. Snape, J. F. et al. Lunar basalt chronology, mantle differentiation and implications for determining the age of the Moon. Earth Planet. Sci. Lett. 451, 149-158 (2016).

7. Snape, J. F. et al. The timing of basaltic volcanism at the Apollo landing sites. Geochim. Cosmochim. Acta 266, 29-53 (2019).

8. Head, J. W. Lunar volcanism in space and time. Rev. Geophys. 14, 265-300 (1976).

9. Snape, J. F. et al. Ancient volcanism on the Moon: insights from Pb isotopes in the MIL 13317 and Kalahari 009 lunar meteorites. Earth Planet. Sci. Lett. 502, 84-95 (2018).

10. Merle, R. E. et al. Pb-Pb ages and initial $\mathrm{Pb}$ isotopic composition of lunar meteorites: NWA 773 clan, NWA 4734, and Dhofar 287. Meteorit. Planet. Sci. 55, 1808-1832 (2020).

11. Hiesinger, H., Head, J. W. III, Wolf, U., Jaumann, R. \& Neukum, G. Ages and stratigraphy of lunar mare basalts in Mare Frigoris and other nearside maria based on crater sizefrequency distribution measurements. J. Geophys. Res. Planets 115, E03003 (2010).

12. Morota, T. et al. Timing and characteristics of the latest mare eruption on the Moon. Earth Planet. Sci. Lett. 302, 255-266 (2011).

13. Qian, Y. Q. et al. Young lunar mare basalts in the Chang'e- 5 sample return region, northern Oceanus Procellarum. Earth Planet. Sci. Lett. 555, 116702 (2021).

14. Wieczorek, M. A. \& Phillips, R. J. The "Procellarum KREEP Terrane": implications for mare volcanism and lunar evolution. J. Geophys. Res. Planets 105, 20417-20420 (2000).

15. Wood, J. A., Dickey, J. S. Jr, Marvin, U. B. \& Powell, B. N. Lunar anorthosites. Science 167, 602-604 (1970).

16. Touboul, M., Kleine, T., Bourdon, B., Palme, H. \& Wieler, R. Late formation and prolonged differentiation of the Moon inferred from W isotopes in lunar metals. Nature 450, 1206-1209 (2007)

17. Nyquist, L. E. \& Shih, C. Y. The isotopic record of lunar volcanism. Geochim. Cosmochim Acta 56, 2213-2234 (1992).

18. Nyquist, L. E. et al. Lunar crustal history recorded in lunar anorthosites. Lunar Planet. Sci. Conf. 41, 1383 (2010)

19. Tian, H.-C. et al. Non-KREEP origin for Chang'e- 5 basalts in the Procellarum KREEP Terrane. Nature, https://doi.org/10.1038/s41586-021-04119-5 (2021).

20. Hess, P. C. \& Parmentier, E. M. Thermal evolution of a thicker KREEP liquid layer. J. Geophys. Res. Planets 106, 28023-28032 (2001).

21. Qian, Y. Q. et al. Geology and scientific significance of the Rümker region in northern Oceanus Procellarum: China's Chang'e-5 landing region. J. Geophys. Res. Planets $\mathbf{1 2 3}$ 1407-1430 (2018).

22. Xie, M., Xiao, Z., Zhang, X. \& Xu, A. The provenance of regolith at the Chang'e- 5 candidate landing region. J. Geophys. Res. Planets 125, e2019JE006112 (2020).

23. Qian, Y. Q. et al. China's Chang'e-5 landing site: geology, stratigraphy, and provenance of materials. Earth Planet. Sci. Lett. 561, 116855 (2021).

24. Neukum, G., Ivanov, B. A. \& Hartmann, W. K. Cratering records in the inner Solar System in relation to the lunar reference system. Space Sci. Rev. 96, 55-86 (2001).

25. Speyerer, E. J., Povilaitis, R. Z., Robinson, M. S., Thomas, P. C. \& Wagner, R. V. Quantifying crater production and regolith overturn on the Moon with temporal imaging. Nature 538, 215-218 (2016).

26. Bogert, C. H. \& Hiesinger, H. Which samples are needed for improved calibration of the lunar cratering chronology? Lunar Planet. Sci. Conf. 51, 2088 (2020).

27. Robbins, S. J. New crater calibrations for the lunar crater-age chronology. Earth Planet. Sci. Lett. 403, 188-198 (2014).

28. Hiesinger, H. et al. How old are young lunar craters? J. Geophys. Res. Planets 117, EOOH1O (2012).

29. Hiesinger, H., Head, J. W. III, Wolf, U., Jaumann, R. \& Neukum, G. in Recent Advances and Current Research Issues in Lunar Stratigraphy (GSA Special Paper 477) (eds Ambrose, W. A. \& Williams, D. A.) 1-51, https://doi.org/10.1130/SPE477 (GSA, 2011).

30. Stöffler, D. \& Ryder, G. Stratigraphy and isotope ages of lunar geologic units: chronological standard for the inner Solar System. Space Sci. Rev. 96, 9-54 (2001). 


\section{Article}

31. Jia, M. et al. A catalogue of impact craters larger than $200 \mathrm{~m}$ and surface age analysis in the Chang'e-5 landing area. Earth Planet. Sci. Lett. 541, 116272 (2020).

32. Xu, Z., Guo, D. \& Liu, J. Maria basalts chronology of the Chang'e- 5 sampling site. Remote Sens. 13, 1515 (2021)

33. Wu, B., Huang, J., Li, Y. Wang, Y. \& Peng, J. Rock abundance and crater density in the candidate Chang'e-5 landing region on the Moon. J. Geophys. Res. Planets 123, 3256-3272 (2018).

34. Le Feuvre, M. \& Wieczorek, M. A. Nonuniform cratering of the Moon and a revised crater chronology of the inner Solar System. Icarus, 214, 1-20 (2011).

35. Marchi, S. et al. A new chronology for the Moon and Mercury. Astronomic. J. 137, 4936-4948 (2009).

36. Wagner, R. et al. Stratigraphic sequence and ages of volcanic units in the Gruithuisen region of the Moon. J. Geophys. Res. 107, 5104 (2002).

37. Hartmann, W. K., Quantin, C. \& Mangold, N. Possible long-term decline in impact rates: 2. Lunar impact-melt data regarding impact history. Icarus 186, 11-23 (2007).
Publisher's note Springer Nature remains neutral with regard to jurisdictional claims in published maps and institutional affiliations.

(c) Open Access This article is licensed under a Creative Commons Attribution 4.0 International License, which permits use, sharing, adaptation, distribution and reproduction in any medium or format, as long as you give appropriate credit to the original author(s) and the source, provide a link to the Creative Commons license, and indicate if changes were made. The images or other third party material in this article are included in the article's Creative Commons license, unless indicated otherwise in a credit line to the material. If material is not included in the article's Creative Commons license and your intended use is not permitted by statutory regulation or exceeds the permitted use, you will need to obtain permission directly from the copyright holder. To view a copy of this license visit http://creativecommons.org/licenses/by/4.0/.

(c) The Author(s) 2021 


\section{Methods}

The sample mounting, scanning electron microscope (SEM), electron probe microanalysis (EPMA) and SIMS analyses were performed at the Institute of Geology and Geophysics, Chinese Academy of Sciences (IGGCAS) in Beijing, China.

\section{SEM analysis}

The Chang'e- 5 basalt clasts studied were first embedded in epoxy mounts and then polished using a grinder. A Thermo Scientific Apreo SEM equipped with an energy dispersive spectroscopy (EDS) detector was used to identify the Zr-bearing and phosphate minerals. High-resolution back-scatter electron (BSE) imaging and semi-quantitative EDS analyses were conducted using a Zeiss Gemini 450 field-emission environmental SEM. For a large-scale BSE imaging of a single basalt clast, the measurement was performed at an acceleration voltage of $15 \mathrm{kV}$ and a current of $2.0 \mathrm{nA}$, with a working distance of about $8 \mathrm{~mm}$. For dated minerals in a localized area, the analyses were operated with an acceleration voltage of $5 \mathrm{kV}$, a beam current of $1.0 \mathrm{nA}$ and a working distance of about $7 \mathrm{~mm}$. The phosphate (apatite and merrillite) and Zr-bearing minerals (baddeleyite, zirconolite and tranquillityite) were examined by EDS (Extended Data Fig. 1).

\section{EPMA analyses for dated minerals}

Both Zr-bearing minerals and phosphate were analysed using a CAMECA SXFive FE electron probe microanalyser. An acceleration voltage of $20 \mathrm{kV}$ and beam current of $30 \mathrm{nA}$ were used for all analyses, with a spot size of $1 \mu \mathrm{m}$. Data were processed with the phi-rho-Z matrix correction using CAMECA PeakSight software (version 6.2). Synthetic glasses (single REE oxide-calcium oxide-aluminium oxide-silicon dioxide) from P\&H Developments were used as the standards for REE. The standards used for the other elements analysed were periclase (magnesium (Mg)), K-feldspar (aluminium (Al)), rhodonite (silicon $(\mathrm{Si})$, calcium $(\mathrm{Ca})$ and manganese $(\mathrm{Mn})$ ), rutile $(\mathrm{Ti})$, chromium oxide (chromium $(\mathrm{Cr})$ ), specularite (Fe), yttrium Al garnet (yttrium $(\mathrm{Y})$, zircon $(\mathrm{Zr})$, niobium metal $(\mathrm{Nb})$, tantalum metal $(\mathrm{Ta})$, tungsten metal $(\mathrm{W})$, cubic zirconia (hafnium $(\mathrm{Hf})$ ), apatite $(\mathrm{P})$, fluorite (fluoride $(\mathrm{F})$ ), halite (chlorine $(\mathrm{Cl})$ ) and celestine (sulfur (S) and $\mathrm{Sr}$ ). The methodology for the analysis of REE followed that of ref. ${ }^{38}$. The detection limits of $\mathrm{Zr}$, REE and Y vary from about 100 ppm to about $300 \mathrm{ppm}$, whereas those for major elements are 60-120 ppm. Representative analysis results for phosphate and $\mathrm{Zr}$-bearing minerals are listed in Supplementary Tables 1, 2, respectively.

\section{SIMS analyses}

The target selection strategy was to identify phases that would contain initial $\mathrm{Pb}$ and those containing radiogenic $\mathrm{Pb}$ generated from in situ decay of U since crystallization of the sample (for example, phosphates and $\mathrm{Zr}$-bearing phases). The distinct $\mathrm{Pb}$ isotopic ratios yielded by these two types of phase help to populate the isochron and calculate a precise date. The target areas within these phases were selected to be large enough to accommodate a SIMS analytical spot (in this case, the smallest spot used was less than $3 \mu \mathrm{m}$ ). The Pb isotopic compositions (complete dataset presented in Supplementary Table 3) of the phases were determined over three analytical sessions using a CAMECA IMS $1280 \mathrm{HR}$ ion microprobe. The mounts with candidate minerals were cleaned with a fine $(0.25 \mu \mathrm{m})$ diamond paste and ethanol to remove the carbon coating before adding a roughly 20 -nm gold coating.

The first session focused on the $\mathrm{Pb}$-isotope measurement of Zr-bearing minerals. A Gaussian illumination mode was used to focus a primary beam of ${ }^{16} \mathrm{O}^{-}$to a size of less than $3 \mu \mathrm{m}$ (about $2.8 \mu \mathrm{m}$ ) (Fig. 1, Extended Data Fig. 2), with an accelerated potential of $-13 \mathrm{kV}$. The beam size can be kept unchanged for a long usage time and intensities were around $250-200 \mathrm{pA}$. The primary beam setting is described in detail in ref. ${ }^{39}$. The multi-collector mode with five electron multipliers with low noise (less than $0.001 \mathrm{cps}$, especially for $\mathrm{L} 2$ ) was used to measure ${ }^{204} \mathrm{~Pb}^{+}(\mathrm{L} 2),{ }^{206} \mathrm{~Pb}^{+}(\mathrm{L} 1),{ }^{207} \mathrm{~Pb}^{+}(\mathrm{C}),{ }^{208} \mathrm{~Pb}^{+}(\mathrm{H} 1)$ and ${ }^{96} \mathrm{Zr}_{2}{ }^{16} \mathrm{O}_{2}{ }^{+}(\mathrm{H} 2)$. The methodology is similar to that outlined in ref. ${ }^{40}$. Exit slit 3 was used, with a mass resolving power (MRP) of 8,000 (50\% peak height). Before analysis, a primary beam of ${ }^{16} \mathrm{O}^{-}$with an intensity of $10 \mathrm{nA}$ was used for 120 s of pre-sputtering. The ion images with ${ }^{96} \mathrm{Zr}_{2}{ }^{16} \mathrm{O}_{2}{ }^{+}$and $\mathrm{Pb}$ isotopes on a $25 \mu \mathrm{m} \times 25-\mu \mathrm{m}$ area were used to precisely locate the target minerals. The signal of ${ }^{206} \mathrm{~Pb}$ was used for peak-centring reference. Each measurement consisted of $4 \mathrm{~s} \times 80$ cycles, with a total analytical time of about $10 \mathrm{~min}$. High-purity oxygen gas was leaked onto the sample surface to enhance the $\mathrm{Pb}^{+}$yield to more than $15 \mathrm{cps} \mathrm{ppm}^{-1} \mathrm{nA}^{-1}$ by using a $\mathrm{O}^{-}$primary beam according to the $\mathrm{M} 257$ zircon standard (561 Ma, 840 ppm U, ref. ${ }^{41}$ ). NIST610 glass and Phalaborwa baddeleyite standard $\left({ }^{207} \mathrm{~Pb}^{*} /{ }^{206} \mathrm{~Pb}^{*}=0.1272\right.$, ref. $\left.{ }^{42}\right)$ were used to calibrate the relative yield of different electron multipliers and evaluate the external reproducibility. On the basis of 21 analyses on NIST 610 glass under the same analytical conditions, the ${ }^{207} \mathrm{~Pb} /{ }^{206} \mathrm{~Pb}$ measurements have a relative standard deviation (1 r.s.d.) of $0.66 \%$ with ${ }^{207} \mathrm{~Pb}$ intensity averaged at $127 \mathrm{cps}$. The possible SIMS instrumental mass fractionation of $\mathrm{Pb}$ isotopes around $0.2 \%$ (ref. $^{43}$ ) was propagated to the uncertainty of single-spot ${ }^{207} \mathrm{~Pb} /{ }^{206} \mathrm{~Pb}$ analysis.

The second session focused on the Pb-isotope measurement of phosphates. A Gaussian illumination mode was used to focus a primary beam of ${ }^{16} \mathrm{O}_{2}{ }^{-}$to a roughly $8-\mu \mathrm{m}$ size with the intensity kept around $2.5 \mathrm{nA}$. Ion images with $\mathrm{Ca}_{2} \mathrm{PO}_{3}{ }^{+}$on a $30 \mu \mathrm{m} \times 30-\mu \mathrm{m}$ area were used to precisely locate the target minerals. The methodology is similar to that outlined in ref. ${ }^{44}$. Exit slit 3 was used, with an MRP of 8,000 (50\% peak height). The dynamic multi-collector mode was used to measure ${ }^{204} \mathrm{~Pb}^{+}(\mathrm{L} 2),{ }^{206} \mathrm{~Pb}^{+}(\mathrm{L} 1)$ and ${ }^{207} \mathrm{~Pb}^{+}(\mathrm{C})$ in the first step with 60-s counting time, and ${ }^{238} \mathrm{U}(\mathrm{L} 1),{ }^{232} \mathrm{ThO}^{+}(\mathrm{H} 1)$ and ${ }^{238} \mathrm{UO}^{+}(\mathrm{H} 2)$ in the second step with 4-s counting time. Each measurement consisted of 10 cycles, with a total analytical time of about 15 min including 2 min of pre-sputtering. NIST610 glass and Phalaborwa baddeleyite $\left({ }^{207} \mathrm{~Pb}^{*} /{ }^{206} \mathrm{~Pb}^{*}=0.1272\right.$; ref. $\left.{ }^{42}\right)$ were used to calibrate the relative yield of different electron multipliers and evaluate the external reproducibility. On the basis of 20 analyses on Phalaborwa baddeleyite under the same analytical conditions, the ${ }^{207} \mathrm{~Pb} /{ }^{206} \mathrm{~Pb}$ measurements show 1 r.s.d. of $0.2 \%$ with ${ }^{207} \mathrm{~Pb}$ intensity averaged at $970 \mathrm{cps}$.

The third session focused on the initial $\mathrm{Pb}$ composition test on the essential minerals (mainly plagioclase and pyroxene) and matrix. A Köhler illumination mode was used to produce a primary beam of about $30 \mathrm{nA} \mathrm{O}_{2}{ }^{-}$to a roughly $30-\mu \mathrm{m}$ size. Before each measurement, an area of $25 \mu \mathrm{m}$ around the spot location was raster-scanned for $120 \mathrm{~s}$ to remove the gold coating and minimize possible surface contamination. The multi-collector mode with five electron multipliers was used to measure ${ }^{204} \mathrm{~Pb}^{+}(\mathrm{L} 2),{ }^{206} \mathrm{~Pb}^{+}(\mathrm{L} 1),{ }^{207} \mathrm{~Pb}^{+}(\mathrm{C})$ and ${ }^{208} \mathrm{~Pb}^{+}(\mathrm{H} 1)$ in the first step with 60 -s counting time, and ${ }^{232} \mathrm{ThO}^{+}(\mathrm{H} 1)$ and ${ }^{238} \mathrm{UO}^{+}(\mathrm{H} 2)$ in the second step with 4-s counting time. Exit slit 3 was used, with an MRP of 8,000 ( $50 \%$ peak height), sufficient to resolve $\mathrm{Pb}$ from known molecular interferences. Each measurement consisted of 10 cycles. On the basis of 28 analyses on NIST614 glass under the same analytical conditions, the ${ }^{207} \mathrm{~Pb} /{ }^{206} \mathrm{~Pb}$ measurements show 1 r.s.d. of $0.68 \%$ with ${ }^{207} \mathrm{~Pb}$ intensity averaged at $120 \mathrm{cps}$.

The background counts for each channel were measured at regular intervals during each session by using deflector and aperture settings that effectively blank both primary and any residual secondary beams. The average background values are reported in Extended Data Table 2. The number of SIMS Pb isotope analyses for each type of basalt clast used in this study are summarized in Extended Data Table 1.

\section{SIMS data processing}

The data were processed using in-house SIMS data reduction spreadsheets and the Excel add-in Isoplot (version 4.15; ref. ${ }^{45}$ ). The $\mathrm{Pb}-\mathrm{Pb}$ isochrons were constructed following the method first established by ref. ${ }^{46}$, then applied to SIMS by ref. ${ }^{6}$ and further expressed and 


\section{Article}

refined by refs. ${ }^{7,10}$. In brief, the $\mathrm{Pb}$ isotopic compositions measured in each sample are interpreted as representing a mixture between three main components: (1) initial $\mathrm{Pb}$ present in the basaltic melt when it crystallized; (2) radiogenic $\mathrm{Pb}$ formed by the decay of $\mathrm{U}$ in the basalt after crystallization; and (3) terrestrial contamination. These end-member components define a triangular array of points on a plot of ${ }^{207} \mathrm{~Pb} /{ }^{206} \mathrm{~Pb}$ versus ${ }^{204} \mathrm{~Pb} /{ }^{206} \mathrm{~Pb}$ (Extended Data Fig. 3). The values with the highest ${ }^{207} \mathrm{~Pb} /{ }^{206} \mathrm{~Pb}$ ratios, those at the top of the triangular array, provide an estimate of the lowest possible value for the initial $\mathrm{Pb}$ composition of the sample. The radiogenic $\mathrm{Pb}$ component is then located where ${ }^{204} \mathrm{~Pb} /{ }^{206} \mathrm{~Pb}=0$. Finally, given the radiogenic $\mathrm{Pb}$ isotopic compositions associated with the Moon relative to those found on Earth, the terrestrial contamination end-member will have the highest ${ }^{204} \mathrm{~Pb} /{ }^{206} \mathrm{~Pb}$ ratios. Any obvious cracks or voids in the sample would be likely places for terrestrial contamination to accumulate during sample polishing and cleaning procedures. Despite the efforts made to avoid such regions, it was difficult to ensure that the SIMS spots did not overlap with small invisible cracks, or did not depth-profile into such features lying just below the original surface of the sample. Furthermore, given the low Pb concentrations in many of the analysed phases (particularly those with lower radiogenic $\mathrm{Pb}$ isotope compositions), these analyses are particularly susceptible to even low levels of terrestrial contamination. On the basis of these assumptions, the bounding edge on the left side of the triangle, between the initial and radiogenic lunar $\mathrm{Pb}$ compositions, forms an isochron, which can be determined by iteratively filtering the data to yield the steepest statistically significant weighted regression. The ${ }^{207} \mathrm{~Pb} /{ }^{206} \mathrm{~Pb}$ of initial $\mathrm{Pb}$ was estimated by spots with the highest ${ }^{207} \mathrm{~Pb} /{ }^{206} \mathrm{~Pb}$ and near-zero ${ }^{238} \mathrm{UO}^{+} /{ }^{208} \mathrm{~Pb}^{+}$(Extended Data Fig. 4), following the procedures of refs. ${ }^{7,10}$.

The $\mathrm{Pb}$ concentrations were estimated based on the $\mathrm{Pb}$ yield assuming that $\mathrm{Zr}$-bearing minerals have comparable $\mathrm{Pb}$ yield with that in zircon (that is, $15 \mathrm{cps} \mathrm{ppm}^{-1} \mathrm{nA}^{-1}$ with a primary beam of $\mathrm{O}^{-}$). Baddeleyite, tranquillityite and zirconolite grains have $U$ contents of approximately $100-4,000 \mathrm{ppm}, 600-7,000 \mathrm{ppm}$ and $800-4,600 \mathrm{ppm}$, respectively, whereas the phosphate grains have lower $U$ contents of approximately 12-150 ppm estimated from $\mathrm{UO}^{+}$yield based on Durango apatite.

\section{Data availability}

All data generated or analysed during this study are available in EarthChem Library at https://doi.org/10.26022/IEDA/112085. Source data are provided with this paper.

\section{Code availability}

No code is used in this study.

38. Williams, C. T. in Rare Earth Minerals: Chemistry, Origin and Ore Deposits (eds Jones, A. P. et al.) 327-348 (Springer, 1996).

39. Liu, Y., Li, X. H., Li, Q. L. \& Tang, G. Q. Breakthrough of 2- to 3- $\mu \mathrm{m}$ scale U-Pb zircon dating using Cameca IMS-1280HR SIMS. Surf. Interface Anal. 52, 214-223 (2O2O).

40. $\mathrm{Li}$, Q. L. et al. Precise $\mathrm{U}-\mathrm{Pb}$ and $\mathrm{Pb}-\mathrm{Pb}$ dating of Phanerozoic baddeleyite by SIMS with oxygen flooding technique. J. Anal. At. Spectrom. 25, 1107-1113 (2010).

41. Nasdala, L. et al. Zircon M257-a homogeneous natural reference material for the ion microprobe U-Pb analysis of zircon. Geostand. Geoanal. Res. 32, 247-265 (2008).

42. Heaman, L. M. The application of U-Pb geochronology to mafic, ultramafic and alkaline rocks: an evaluation of three mineral standards. Chem. Geol. 261, 43-52 (2009).

43. Stern, R. et al. Measurement of SIMS instrumental mass fractionation of $\mathrm{Pb}$ isotopes during zircon dating. Geostand. Geoanal. Res. 33, 145-168 (2009).

44. Li, Q. L. et al. In-situ SIMS U-Pb dating of Phanerozoic apatite with low $U$ and high common Pb. Gondwana Res. 21, 745-756 (2012).

45. Ludwig, K. R. Isoplot 4.15: a geochronological toolkit for Microsoft Excel (Berkeley Geochronology Center, 2008)

46. Connelly, J. N. et al. The absolute chronology and thermal processing of solids in the solar proto-planetary disk. Science 338, 651-655 (2012).

47. Steiger, R. H. \& Jäger, E. Subcommission on geochronology: convention on the use of decay constants in geo- and cosmochronology. Earth Planet. Sci. Lett. 36, 359-362 (1977).

48. Hiess, J., Condon, D. J., McLean, N. \& Noble, S. R. ${ }^{238} \mathrm{U} /{ }^{235} \mathrm{U}$ systematics in terrestrial uranium-bearing minerals. Science 335, 1610-1614 (2012)

49. Göpel, C., Manhès, G. \& Allègre, C. J. U-Pb systematics in iron meteorites-uniformity of primordial lead. Geochim. Cosmochim. Acta 49, 1681-1695 (1985).

Acknowledgements We thank all the staff of China's Chang'e Lunar Exploration Project for their hard work in returning lunar samples. The samples studied in this work were allocated by the China National Space Administration. We thank R. Mitchell for constructive comments and editing the manuscript; W. Yang, Y. Chen, H.-J. Hui and H.-C. Tian for helpful discussion; and C. Sun for logistical support. This study was funded by the Key Research Program of the Chinese Academy of Sciences (ZDBS-SSW-JSC007-13), the Institute of Geology and Geophysics, Chinese Academy of Sciences (IGGCAS-202101), the National Natural Science Foundation of China (41773044) and the pre-research project on Civil Aerospace Technologies of China National Space Administration (grant number D020203).

Author contributions X.-H.L. and C.L. conceived and supervised this project. Q.-L.L., Q.Z., and Z.X. wrote the manuscript with input of X.-H.L., C.L., Y.L. and F.-Y.W. H.-X.M. and J.L. conducted sample mounting. Q.Z., J.-H.L., X.T., S.G. and J.-Y.Y. performed SEM and EPMA analyses. Q.-L.L. Y.L., G.-Q.T. and Q.Z. conducted SIMS analyses, data processing and interpretation. Z.O. and F.-Y.W. contributed scientific background and geological context.

Competing interests The authors declare no competing interests.

\section{Additional information}

Supplementary information The online version contains supplementary material available at https://doi.org/10.1038/s41586-021-04100-2.

Correspondence and requests for materials should be addressed to Chunlai Li or Xian-Hua Li. Peer review information Nature thanks Charles Shearer and Renaud Merle for their contribution to the peer review of this work. Peer reviewer reports are available. Reprints and permissions information is available at http://www.nature.com/reprints. 

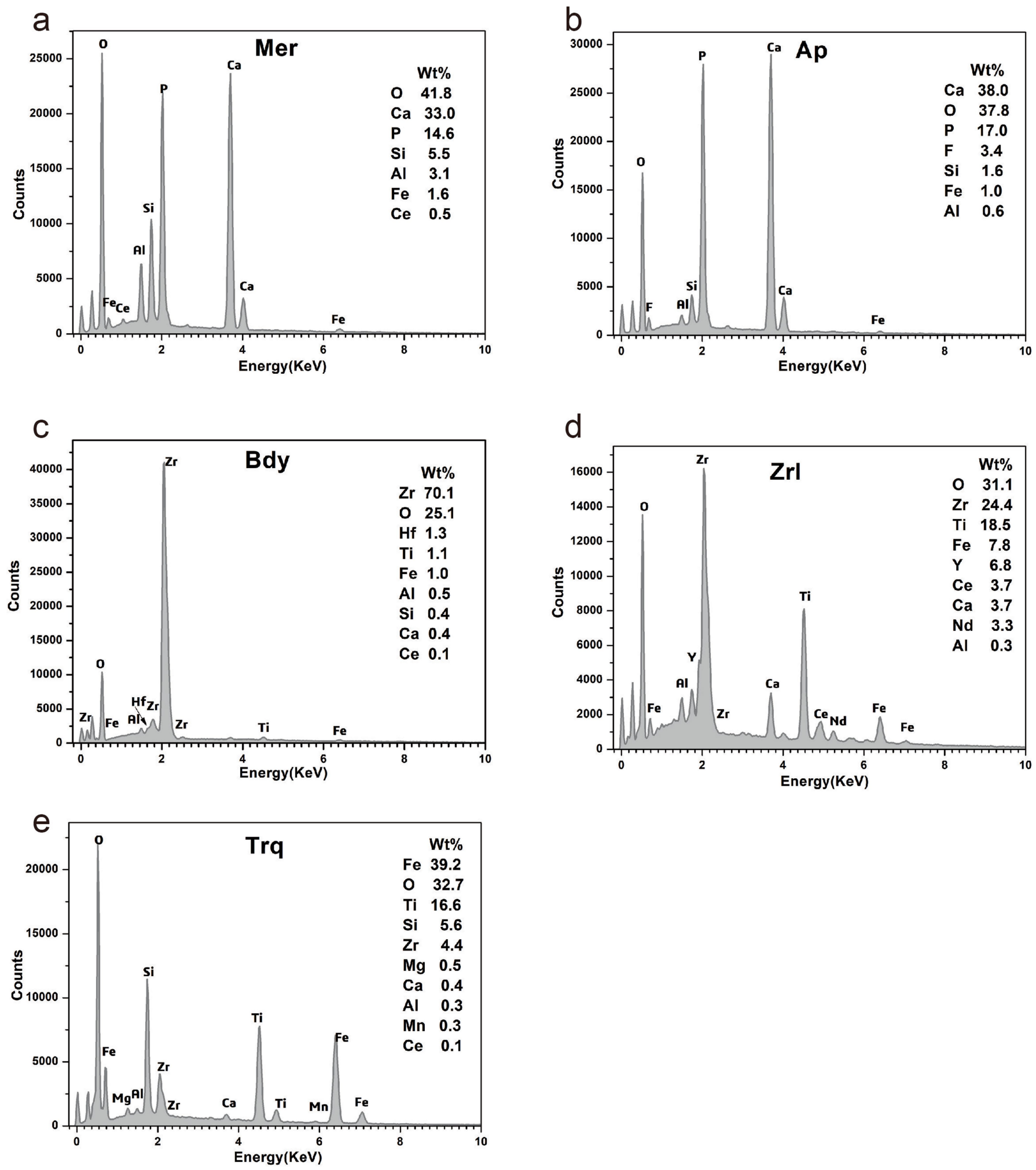

Extended Data Fig. 1 | Plots of the representative energy dispersive X-ray spectrum for dated minerals. Element concentrations detected by EDS are also shown for comparison. Mer, merrillite; Ap, apatite; Bdy, baddeleyite; Zrl, zirconolite; Trq, tranquillityite. 


\section{Article}
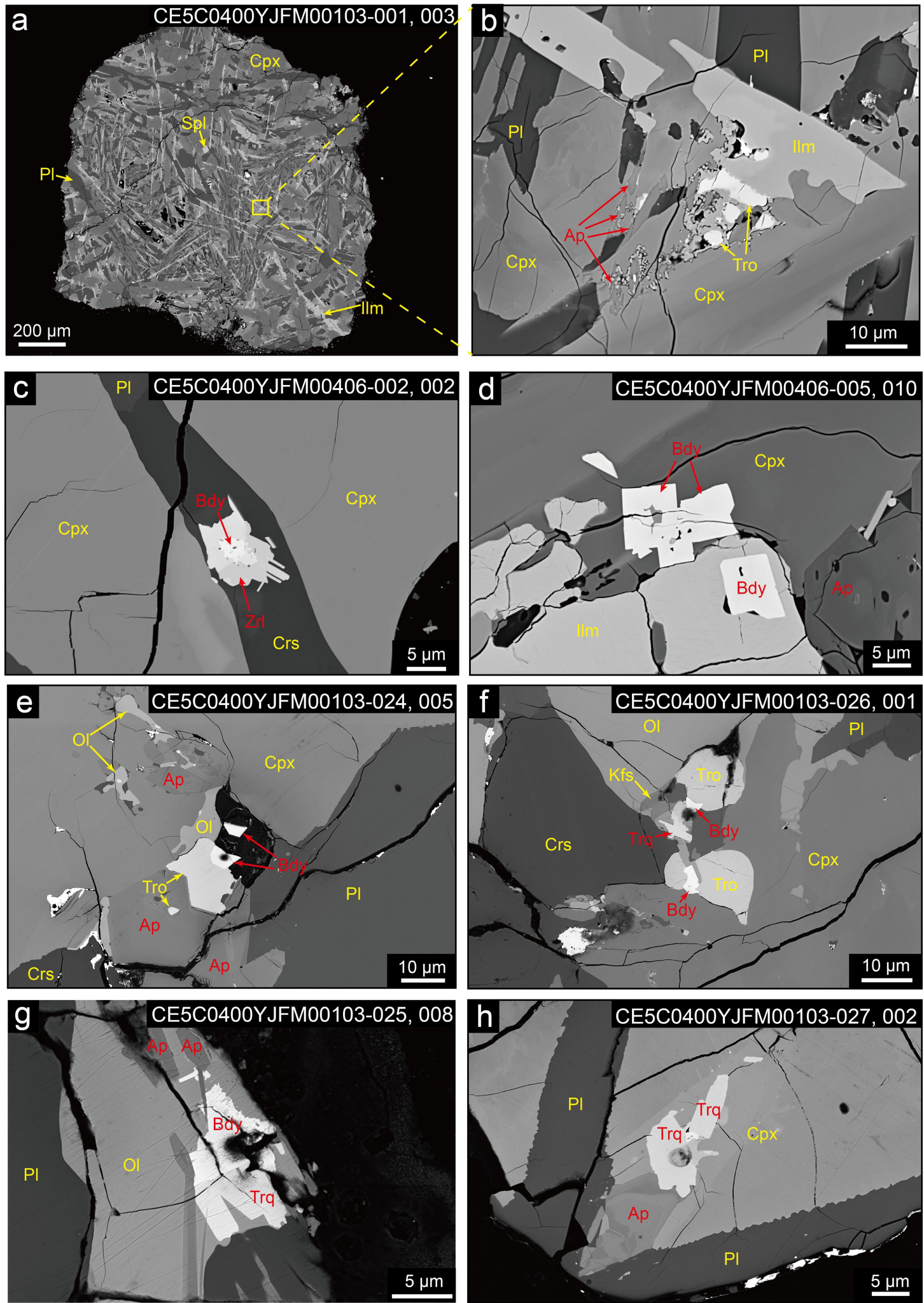

Extended Data Fig. 2 | Microtextures of dated minerals in the Chang'e-5 basalt clasts. a, b, A porphyritic basalt clast that contains fine-grained $(2 \times 10 \mu \mathrm{m})$ apatite grains. The yellow rectangle in $\mathbf{a}$ is expanded in $\mathbf{b}$. The apatite occurs as inclusions in Fe-rich clinopyroxene and is surrounded by tiny ilmenite aggregates. $\mathbf{c}$, In a poikilitic clast, baddeleyite is rimmed by zirconolite.d, Square-shaped baddeleyite inclusions in clinopyroxene and ilmenite from an equigranular clast. Hexagonal apatite exhibits an intergranular phase between clinopyroxene and ilmenite.e, Euhedralsubhedral apatite and baddeleyite show an equilibrium texture with Fe-rich

olivine (Fo < 10), clinopyroxene, and troilite.f, Baddeleyite and tranquillityite show intergrowths along the margins of clinopyroxene and Fe-rich olivine. $g$, In an equigranular clast, baddeleyite, tranquillityite and apatite are intergrown with Fe-rich olivine. $\mathbf{h}$, Tranquillityite and apatite intergrown crystals in a poikilitic clast. Blurry pits in Zr-bearing minerals are the analytical spots from SIMS. Bdy, baddeleyite; Zrl, zirconolite; Trq, tranquillityite; Mer, merrillite; Ap, Apatite; $\mathrm{Cpx}$, clinopyroxene; $\mathrm{Ol}$, olivine; $\mathrm{Pl}$, plagioclase; Kfs, K-feldspar; Ilm, ilmenite; Crs, cristobalite; Tro, troilite; Spl, spinel. 

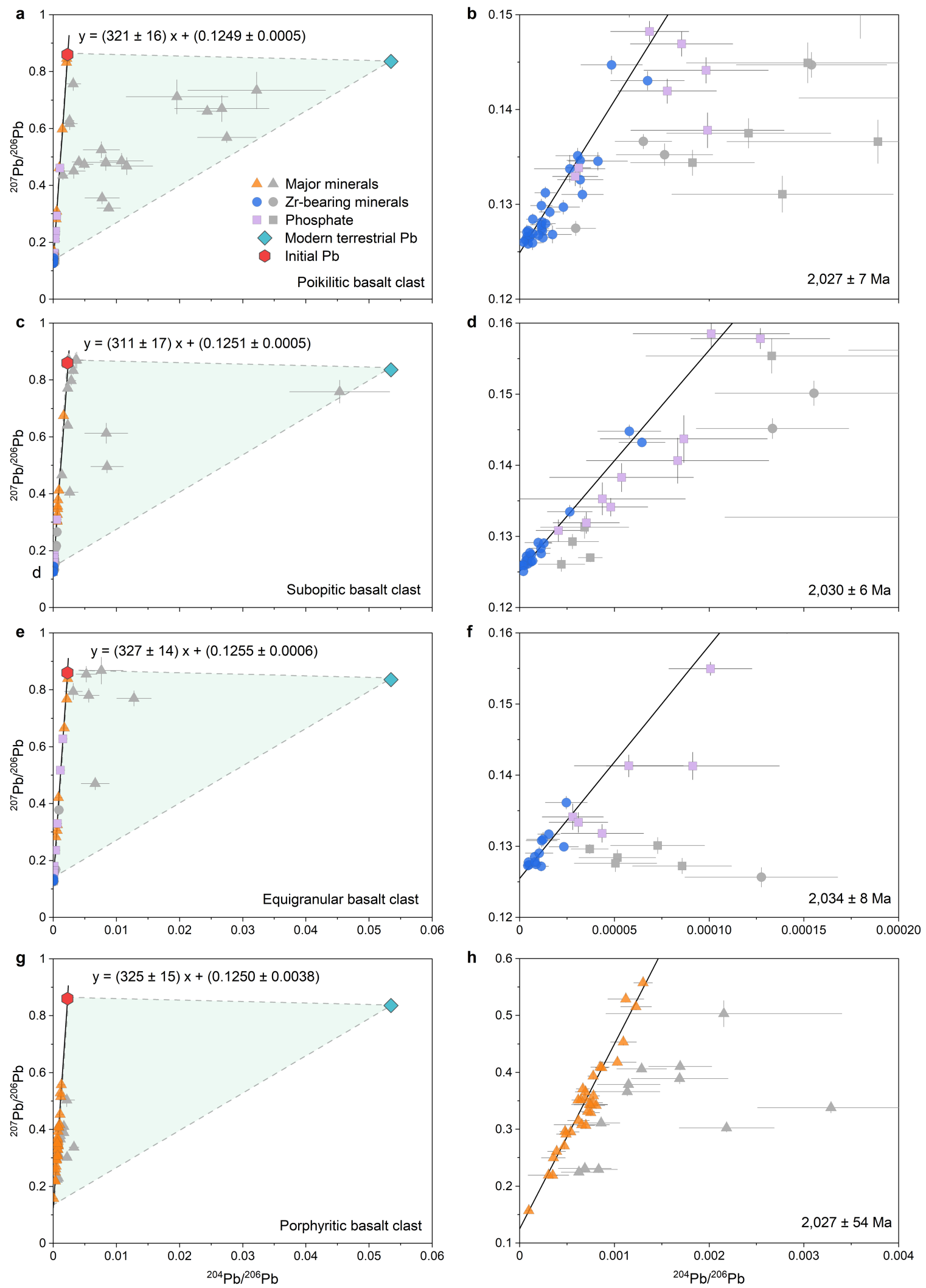

h

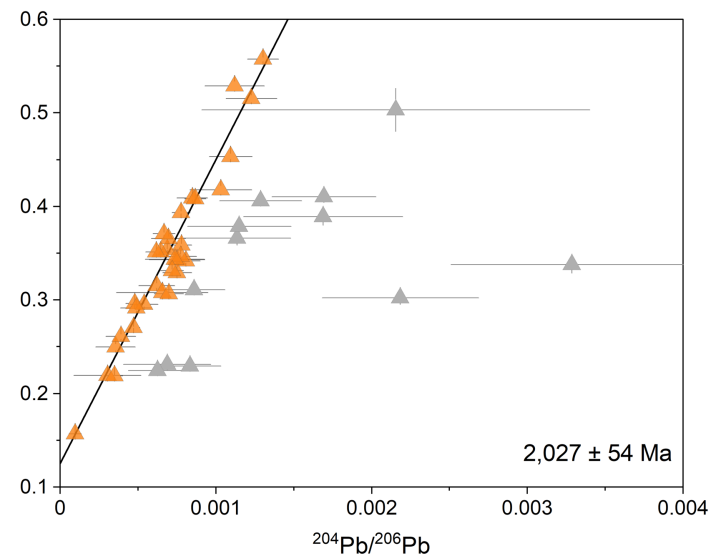

Extended Data Fig. $3 \mid \mathbf{P b}$-Pb isochrons for the Chang'e- 5 basalts with different textures. The left four plots (a, c, e and $\mathbf{g}$ ) show the data from basalt clasts with poikilitic, subophitic, equigranular and porphyritic textures, respectively. The equations of isochrons (black lines) are shown on the top. The right four plots (b, d, f and $\mathbf{h}$ ) are the enlarged lowest portions of the isochrons highlighting the measurements with $l o{ }^{204} \mathrm{~Pb} /{ }^{206} \mathrm{~Pb}$. The red hexagon represents the initial $\mathrm{Pb}$ determined from the integrated isochron, but is not

included in each separated isochron. The triangle areas represent the mixing trend among the initial $\mathrm{Pb}$ component, the radiogenic $\mathrm{Pb}$, and current terrestrial $\mathrm{Pb}$ composition. Outliers excluded from the calculation of the isochron regression are shown in grey while those data used for the leftmost isochron are shown in colour. Error bars represent $1 \sigma$ standard error. The uncertainties for the isochron dates are quoted at the $95 \%$ confidence level. 


\section{Article}

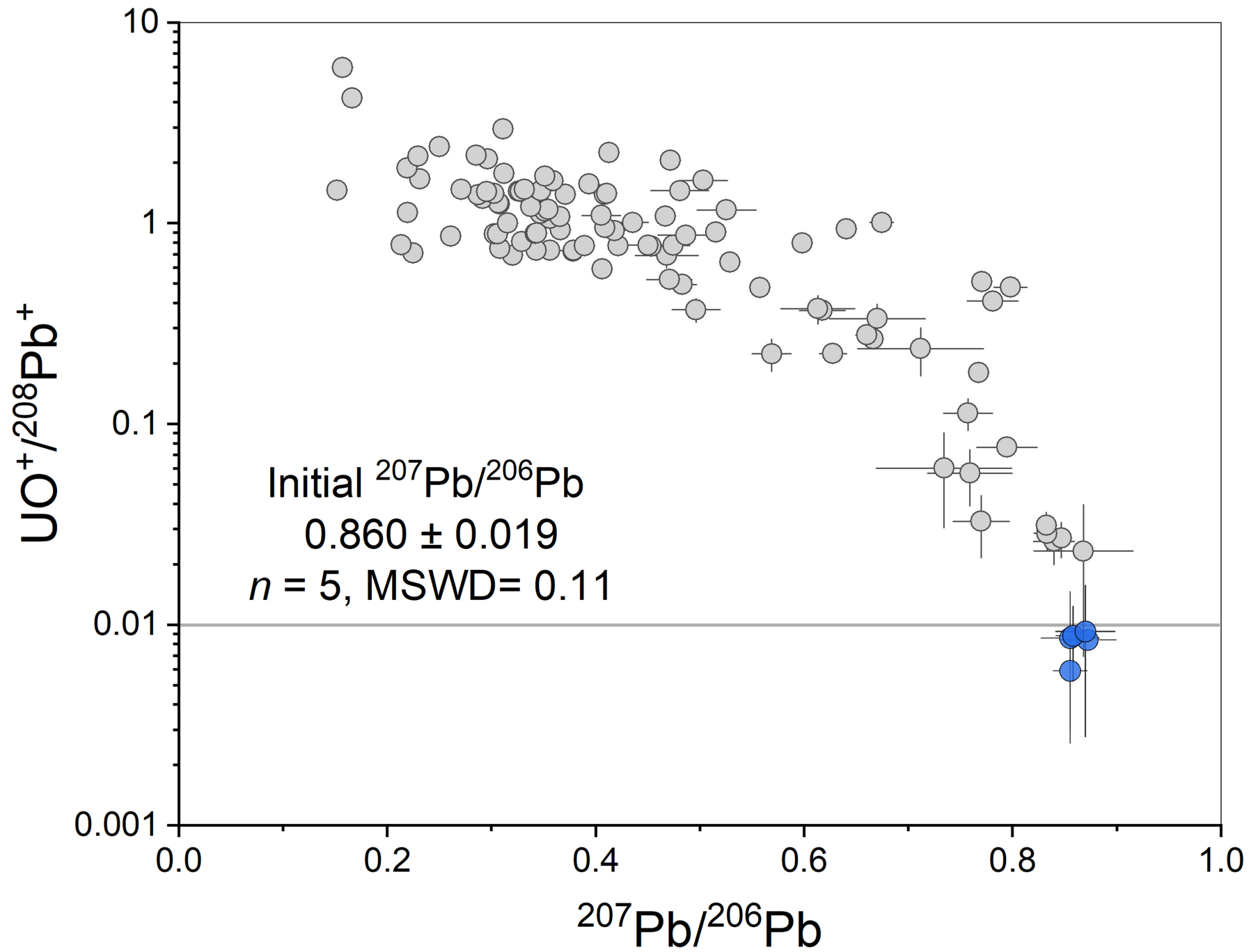

Extended Data Fig. $4 \mid \mathrm{Plot}$ of $\mathrm{UO}^{+} /{ }^{208} \mathrm{~Pb}^{+}$versus ${ }^{207} \mathrm{~Pb} /{ }^{206} \mathrm{~Pb}$ for points within the analysed main rock-forming minerals. Five blue dots highlight the points with $\mathrm{UO}^{+} /{ }^{208} \mathrm{~Pb}^{+}<0.01$ (the grey line), that most likely represent the best estimate for the initial $\mathrm{Pb}$ composition. Note that the measured $\mathrm{UO}^{+} /{ }^{208} \mathrm{~Pb}^{+}$ ratios are simply used here to provide an indication of the $\mathrm{U} / \mathrm{Pb}$ ratios. Error bars represent $1 \sigma$ standard error. 
a

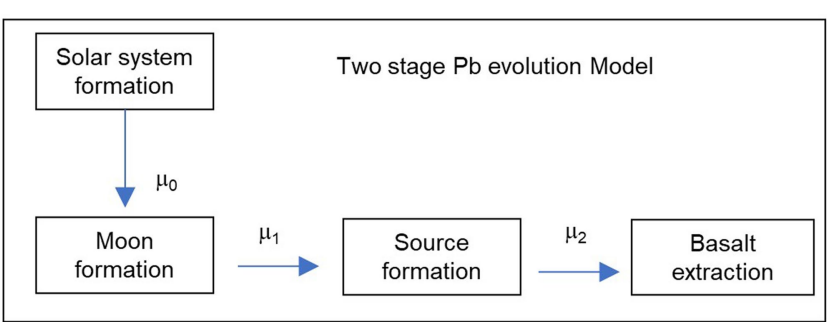

b

Equations used in two stage $\mathrm{Pb}$ evolution Model

$$
\begin{aligned}
& \frac{{ }^{206} \mathrm{~Pb}}{{ }^{204} \mathrm{~Pb}}={\frac{{ }^{206} \mathrm{~Pb}}{{ }^{204} \mathrm{~Pb}}}_{\text {moon }}+\mu_{1}\left(e^{\lambda_{1} T}-e^{\lambda_{1} t_{1}}\right)+\mu_{2}\left(e^{\lambda_{1} t_{1}}-e^{\lambda_{1} t_{2}}\right) \\
& \frac{{ }^{207} \mathrm{~Pb}}{{ }^{204} \mathrm{~Pb}}={\frac{{ }^{207} \mathrm{~Pb}}{{ }^{204} \mathrm{~Pb}}}_{\text {moon }}+\frac{\mu_{1}\left(e^{\lambda_{2} T}-e^{\lambda_{2} t_{1}}\right)+\mu_{2}\left(e^{\lambda_{2} t_{1}}-e^{\lambda_{2} t_{2}}\right)}{137.818}
\end{aligned}
$$

\begin{tabular}{cccc}
\hline Basic Parameters & $\lambda_{1}$ & $\lambda_{2}$ & ${ }^{235} \mathrm{U} /{ }^{238} \mathrm{U}$ \\
\hline & $1.55125 \mathrm{E}-10$ & $9.8485 \mathrm{E}-10$ & 0.007256 \\
\hline
\end{tabular}

\begin{tabular}{|c|c|c|c|c|c|c|}
\hline Known values & Age (Ma) & ${ }^{206} \mathrm{~Pb} /{ }^{204} \mathrm{~Pb}$ & ${ }^{207} \mathrm{~Pb} / 204 \mathrm{~Pb}$ & ${ }^{204} \mathrm{~Pb} /{ }^{206} \mathrm{~Pb}$ & ${ }^{207} \mathrm{~Pb} / 206 \mathrm{~Pb}$ & $\mu\left({ }^{238} \mathrm{U} / 204 \mathrm{~Pb}\right)$ \\
\hline Solar system & 4567 & 9.307 & 10.294 & 0.1074 & 1.106 & 8 \\
\hline Moon formation & 4500 & 9.475 & 10.63 & 0.1055 & 1.122 & $462 \pm 46$ \\
\hline Sample extraction & $2030 \pm 4$ & $439 \pm 21$ & $377 \pm 19$ & $0.00228 \pm 0.00011$ & $0.860 \pm 0.019$ & \\
\hline
\end{tabular}

d

e

\begin{tabular}{|c|c|c|c|c|c|c|}
\hline Age (Ma) & ${ }^{206} \mathrm{~Pb} / 204 \mathrm{~Pb}$ & ${ }^{207} \mathrm{~Pb} / 204 \mathrm{~Pb}$ & $\mu_{2}$ from ${ }^{238} \mathrm{U}-{ }^{206} \mathrm{~Pb}$ & Error & $\mu_{2}$ from ${ }^{235} \mathrm{U}-207 \mathrm{~Pb}$ & Error \\
\hline 4420 & 20.88 & 31.89 & 679 & 36 & 677 & 40 \\
\hline 4400 & 23.71 & 36.95 & 681 & 37 & 681 & 42 \\
\hline 4380 & 26.53 & 41.91 & 684 & 38 & 686 & 44 \\
\hline $4376 \pm 18$ & 27.09 & 42.89 & 684 & 40 & 687 & 46 \\
\hline 4360 & 29.34 & 46.77 & 686 & 39 & 691 & 46 \\
\hline 4340 & 32.14 & 51.54 & 688 & 40 & 696 & 48 \\
\hline 4320 & 34.93 & 56.22 & 691 & 41 & 702 & 50 \\
\hline 4300 & 37.72 & 60.80 & 693 & 42 & 707 & 52 \\
\hline 3350 & 160.5 & 200.9 & 893 & 117 & 1233 & 261 \\
\hline
\end{tabular}

$\mu_{2}$ values with different model ages

Extended Data Fig. 5 | The two-stage Pb evolution model and $\mu$ value calculation procedures. $\mathbf{a}$, The schematic diagram of two-stage $\mathrm{Pb}$ evolution model $^{6} . \mathbf{b}$, The equations used in the two-stage Pb evolution model. c, The basic parameters used, including the decay constant of ${ }^{238} U$ and ${ }^{235} U^{47}$ and ${ }^{235} U /{ }^{238} U$ ratio $^{48}$.d, The summarized parameters from previous work ${ }^{6,49}$ and this study. e, The calculated $\mu$ value based on different modelled ages. 


\section{Article}

Extended Data Table 1 | Summary of SIMS Pb isotope analyses for each type of Chang'e-5 basalt clast

\begin{tabular}{|c|c|c|c|c|c|c|}
\hline & & Poikilitic & Subophitic & Equigranular & Porphyritic & Total \\
\hline \multicolumn{2}{|c|}{ Basalt clast numbers } & 17 & 18 & 10 & 2 & 47 \\
\hline \multirow{3}{*}{$\begin{array}{c}\text { Zr-bearing } \\
\text { minerals grains }\end{array}$} & Baddeleyite & 17 & 12 & 6 & 0 & 35 \\
\hline & Tranquillityite & 3 & 3 & 1 & 0 & 7 \\
\hline & Zirconolite & 4 & 2 & 3 & 0 & 9 \\
\hline \multicolumn{2}{|c|}{ Phosphate grains } & 15 & 15 & 10 & 0 & 40 \\
\hline \multicolumn{2}{|c|}{ Plagioclase + pyroxene + matrix } & 27 & 22 & 13 & 44 & 106 \\
\hline \multicolumn{2}{|c|}{ Isochron Age (Ma) } & $2,027 \pm 7$ & $2,030 \pm 6$ & $2,034 \pm 8$ & $2,027 \pm 54$ & $2,030 \pm 4$ \\
\hline
\end{tabular}


Extended Data Table 2 | Background measurements for electron multiplier collectors

\begin{tabular}{ccccccccc}
\hline $\begin{array}{c}\text { EM collectors } \\
\text { used for }\end{array}$ & \multicolumn{2}{c}{ L2 } & \multicolumn{2}{c}{ L1 } & \multicolumn{2}{c}{ C } & \multicolumn{2}{c}{ H1 } \\
\hline Session 1 $(\mathrm{n}=20)$ & 0.00071 & 0.00134 & 0.00412 & 0.00315 & 0.00355 & 0.00141 & 0.00071 & 0.00109 \\
Session 2 $(\mathrm{n}=30)$ & 0.00057 & 0.00145 & 0.00055 & 0.00145 & 0.00046 & 0.00104 & 0.00037 & 0.00104 \\
Session 3 $(\mathrm{n}=25)$ & 0.00087 & 0.00143 & 0.00050 & 0.00116 & 0.00063 & 0.00156 & 0.00050 & 0.00147 \\
\hline
\end{tabular}

The values presented here are the average values of the measured backgrounds for each session.

The errors are $1 \sigma$ standard deviations of the average values. 